\title{
Influence of personality in buying consumer goods-a comparative study between neo-Freudian theories and trait theory based on Khulna region
}

\author{
Sandip Sarker ${ }^{1}$, Tarun Kanti Bose ${ }^{1}$, Mollika Palit ${ }^{2}$, Md. Enamul Haque ${ }^{2}$ \\ ${ }^{1}$ School of Management and Business Administration, Khulna University \\ ${ }^{2}$ Business Administration Discipline, Khulna University, Khulna-9208, Bangladesh
}

\section{Email address:}

sandip.smiling@gmail.com(S. Sarker), tarun84ku@yahoo.com(T. K. Bose), mpalit_ku@yahoo.com(M. Palit), heera_mkt@yahoo.com(M. E. Haque)

To cite this article:

Sandip Sarker, Tarun Kanti Bose, Mollika Palit, Md. Enamul Haque. Influence of Personality in Buying Consumer Goods-A Comparative Study between Neo-Freudian Theories and Trait Theory Based on Khulna Region. International Business and Economics Research. Vol. 2, No. 3, 2013, pp. 41-58. doi: 10.11648/j.ijber.20130203.12

\begin{abstract}
Consumer's attitudes play a direct and influential role in consumer behavior. Attitude study is important for the marketers of service organization because it affects consumer's selective processes, learning and ultimately the buying behavior. Measuring consumer's attitudes may help a service marketer to get a better picture on both present and potential markets. This paper has explored the factors that create personality problems in consumer buying decision making particularly among the consumer goods purchaser in the Khulna metropolitan area. At first a structured questionnaire has been developed measuring 9 constraints variable for two theories. The factors creating personality problem in consumer buying decision in Khulna metropolitan area have been evaluated by those 9 variables in the form of: compliant, aggressive, detached for the neo-Freudian theory and dogmatism, need for uniqueness, social character, consumer innovativeness, ethnocentrism and compulsiveness for trait theory. The relationship of the variables was evaluated by the survey outcomes. Results show that several factors are influential in creating personality problems among the customers of consumer goods in Khulna region. Some of these are compliant, aggressive, detached, dogmatism, ethnocentrism. The study also reveals the problems and identified probable solutions to overcome these problems.
\end{abstract}

Keywords: Personality, Attitudes, Consumer Behavior, Buying Behavior

\section{Introduction}

\subsection{Background of the Study}

Personality is one of the most heavily studied concepts in consumer behavior. Personality is the result of social and environmental influences on the person concentrated. We can say that personality of an individual is the sum total of his hereditary. One individual is different from others not only in the physical aspects, but also in personality types. It is one of the factors that influence one's behavior in the marketplace. What a consumer purchases, when and how he or she purchases are influenced by his personality types. That is why marketers are interested in understanding the meaning of personality and traits as well as how these traits affect consumer behavior.
We know that attitudes are learned predispositions to respond an object. Customers hold attitude toward a variety of objects that are important to marketer. Also it theoretically summarizes a consumer's evaluation of an object and represents positive and negative feelings and behavioral tendencies. The attitude behavior link does not always hold; many other functions can affect behavior. Attitude can be positive or negative. Marketers and psychologists know that consumers' attitudes are the mixtures of belief, feelings and tendencies lead to favorable responses resulting in purchase. An individual's attitude constitute his mental set that affect how he or she will view something such as a window provides a framework for our view into or out of a house (John W. Newstrom and Keith Davis; 2008).Modern-day business world is very much competitive and the success in the competition is achieved mainly through giving satisfaction to the ultimate consumer. 
In service oriented industry, it is very difficult to set a standard rule to satisfy customers. Several factors influence customer's decision making to take the service from an organization. Consumer goods industry is a service industry.

This industry provides customers with variety of consumer goods which are necessary to meet day to day demand. In a consumer goods industry there are plenty of product lines and different consumers purchase different products to meet their demand. Here personality plays an important role in purchasing their desired products. Therefore it is important for the marketers to identify different personality traits on their target group of customers, how they influences and deliver services accordingly. This study will help to identify different personality traits which are on consumer's mind, how they influences in purchasing consumer goods and therefore helps the marketers to make future decision based on their influences on personality traits.

\subsection{Rationale of the Study}

Understanding the individual person in his or her role as a consumer should be a key issue in the study of consumer behavior, but in order to realize this vision the scope of personality research has to be broadened. Several studies have been conducted on personality traits in relation to the product and brand preferences. Personality is a useful concept because it enables us to categorize consumers into different groups on the basis of one or even several traits. If each person were different in terms of all personality traits, it would be impossible to group consumers into segments and there would be little reason for marketers to develop products and promotional campaigns targeted to particular segments.

We know service industry is a huge industry and success in this study largely depends on identifying target markets and satisfying target customers. Different factors might influence customers to switch one brand to another if it doesn't match with their personality. Since customers are the king in the service industry it is therefore essential to satisfy customers through their offerings. Therefore marketers should remain careful that the services they are offering match with their target customer's personality.

This study will help to find out the determinants that cause personality problem in purchase decision. This study will also help to find out the probable solutions of the problems faced by the service industry in terms of personality traits.

\subsection{Objectives of the Study}

Main Objective: The objective of the study is to identify the influence of personality in buying consumer goods with a comparison between Neo-Freudian theory and Trait theory.

\section{Sub-objectives:}

- Analyze different personality traits which are dominant in buying consumer goods.

- Identifying different attributes in consumer goods industry which develop different personality traits.

- Measuring the importance of each attributes.

- Make a sound comparison between trait theory and neoFreudian theory and identify the best one.

- Measuring problems and identifying probable solutions in controlling different personality traits by the consumer goods industry.

\section{Literature Review and Conceptual Framework}

\subsection{Consumer Behavior}

Consumer behavior is the decision processes and acts of people involved in buying and using products. It involves purchasing and other consumption related activities of people engaging in the exchange process. Behavior of consumer is motivated or purposive. The behavior is directed towards the goal of obtaining products or other resources. It is the activities of people engaged in actual and potential use of market items-whether products, services, retail environments or ideas (Harold W. Berkman and Christopher C. Gilson 1986).

The better the firm understands its consumers, the more likely it becomes successful in the marketplace. Knowledge of consumer behavior would render immense help for planning and implementing marketing strategies. Consumer response is the ultimate taste of whether a marketing strategy will succeed. Thus knowledge of consumer should be incorporated into every facet of a successful marketing plan. And this knowledge also helps to ensure that product continues to appeal to its core market.

\subsection{Factors Affecting Consumer Behavior}

Consumer is the principal priority of business. The efficiency with which a free market system enterprise operates, depends upon the extent of consumer understanding processed by the business community. A business community that is ignorant of consumer preferences can't fulfill its obligations in a meaningful and responsive manner (Leon G. Schiff man and Leslie Lazar kanuk 2008). The study of Consumer behavior includes the study of what they buy, why they buy, how they buy, when they buy, from where they buy, and how often they buy. An open-minded consumer-oriented approach is imperative in today's diverse global marketplace so a firm can identify and serve its target market, minimize dissatisfaction, and stay ahead of competitors. Final consumers purchase for personal, family, or household use. Meanwhile, there are various other factors influencing the purchases of consumer such as (Bhasin. H, 2006).

- Social

- cultural 
- Personal

- Psychological

Cultural: Consumer behavior is deeply influenced by cultural factors such as: buyer culture, subculture, and social class. Culture is the most basic cause of a person's wants and behavior. Growing up, children learn basic values, perception and wants from the family and other important groups. Marketers are always trying to spot "cultural shifts" which might point to new products that might be wanted by customers or to increased demand.

Social: Social factors also impact the buying behavior of consumers. The important social factors are: reference groups, family, role and status. A customer's buying behavior is also influenced by social factors, such as the groups to which the customer belongs and social status.

Each culture contains "sub-cultures" - groups of people with share values. Sub-cultures can include nationalities, religions, racial groups, or groups of people sharing the same geographical location. Sometimes a sub-culture will create a substantial and distinctive market segment of its own. For example, the "youth culture" or "club culture" has quite distinct values and buying characteristics from the much older "gray generation". People belonging to a particular social class tend to have similar beliefs, life styles and buying patterns.

Personal: Personal factors can also affect the consumer behavior. Some of the important personal factors that influence the buying behavior are: lifestyle, economic situation, occupation, age, personality and self concept. For example: a marketing manager of an organization will try to purchase business suits, whereas a low level worker in the same organization will purchase rugged work clothes or young people prefer to wear stylish cloths. It is determined by customer interests, opinions and activities and shapes his whole pattern of acting and interacting in the world.

Psychological: There are four important psychological factors affecting the consumer buying behavior like perception, motivation, learning and beliefs. Consumers can belong to a variety of reference group of people with whom the individual look for association, information and standard of behavior. Their values beliefs can have significant impact on consumer buying pattern. Customer possesses specific belief and attitude towards various products. Since such beliefs and attitudes make up brand image and affect consumer buying behavior therefore marketers are interested in them. Marketers can change the beliefs and attitudes of customers by launching special campaigns in this regard. Customers try to interpret the information in a way that will support what the customers already believe. Similarly, in case of selective retention, marketers try to retain information that supports their beliefs.

\subsection{Definition of Personality}

Personality is the result of social and environmental influences on the person concentrated. We can say that personality of an individual is the sum total of his hereditary. One individual is different from others not only in the physical aspects, but also in personality types. It is the result of the social and environmental influences on the person concerned. Generally speaking, it is the total of many personal and individual characteristics that determine his response tendencies to the environmental stimuli. Since individual do react fairly consistently in a variety of environmental situations, these generalized patterns of response or modes of coping with the world can be called personality (Harrold H. Kasssarjian 1981).

In any one person, certain personality traits dominate others as a result of which people are labeled as aggressive, complaint, aloof, friendly, charismatic or obnoxious. It is a concept which accounts for the apparent consistencies and regularities of behavior over time and across a variety of situations (Lawrence A. Parvin 1996).

Personality has been understood as a unique way in which traits, attitudes, and aptitudes are organized in an individual and this draws attention to the ways in which individuals differ from one another through the peculiar configuration of traits 7 other characteristics each possesses. Each consumer is unique in terms of his or her ambitiousness, competitiveness, conservatism degree of extroversion and so on (Melvin H. Marx and William A. Hillix).

Personality reflects individual differences. It is a useful concept because it enables us to categorize consumers into different groups on the basis of one or several traits. If each person is different in terms of all personality traits, it would be impossible to group consumers into different segments. Personality is consistent and enduring. Although marketers can't change consumer personalities to conform to their products, if they know which personality characteristics influence specific consumer responses, they can attempt to appeal to the relevant traits inherent in their target group of customers. Finally personality can change. An individual's personality is not only in response to abrupt events but also as part of a gradual maturing process.

\subsection{Theories of Personality}

There are quite a few theories of personality developed by researchers based on their own interpretation of personality traits. Some of the major theories are:

- Neo-Freudian Theory

- Socio psychoanalytic Theory

- Gestalt Theory

- Stimulus Response theory

- Cognitive theory

- Trait Theory.

Neo-Freudian theory: Neo-Freudian theory believes that social relationships are fundamental to the formation and development of personality. For instance, Alfred Adler viewed human beings as seeking to attain various rational goals which he called style of life. He also placed much emphasis on the individual efforts to overcome feelings of 
inferiority e.g. by striving for superiority. The term NeoFreudian has both been used to describe those who left the psychoanalytic society and formed their own schools of thought. These new theories, however, hold many of the same underlying beliefs of psychoanalysis, most importantly the view of the unconscious as an important drive in human emotions, cognitions, and behaviors. According to Harry Stack Sullivan people continuously attempt to establish significant and rewarding relationships with others. He was particularly concerned with the individual effort to reduce tensions, such as anxiety. Many marketers use some of these neo-Freudian theories intuitively. For example, marketers who position their products or services as providing an opportunity to belong or to be appreciated by others in a group or social setting would seem to be guided by characterization of the detached individual (Leon G. Schiff man and Leslie Lazar kanuk 2008).

Trait Theory: Trait theory represents a quantitative approach to the study of personality. This theory postulates that an individual's personality is composed of definite predisposition attributes called traits. A trait is more specifically defined as any distinguishable, relatively enduring way in which one individual differs from another. In trait theory personality typically is described as having one or more such characteristics as compulsiveness, ambitiousness, gregariousness, dogmatism, authoritarianism, ethnocentrism, introversion, extroversion, aggressiveness and competitiveness. Trait researchers have found that it is generally more realistic to expect personality to be linked to how customers make their choices and to the purchase or consumption of a broad product category rather than a specific brand (Leon G. Schiffman and Leslie Lazar kanuk 2008).

\subsection{How Personality Affects Consumer Buying Decision Making}

The most challenging concept in marketing deals with understanding why buyers do what they do (or don't do). But such knowledge is critical for marketers since having a strong understanding of buying behavior will help shed light on what is important to customer and also suggest the important influences on customer decision making. It is logical to assume that personality differences should correspond with differences in products purchased by consumers. Researchers tried to find relationships among personality types and buying behavior. Though a few relationships were identified, but the results of many studies have been inconclusive. Consumers purchase products to reflect their personality. The type of house cloths furniture, appliances, automobiles, jewelry people buy may reflect their personalities. It is seen that people of higher class tend to purchase highly priced products. Marketers therefore develop their products and advertising and promotional campaigns keeping in mind the personality types of their target customers (Bhasin. H, 2006).

Today people are very concerned about their image and the status in the society which is a direct outcome of their material prosperity. The profession or the occupation a person is in again has an impact on the products they consume. The status of a person is projected through various symbols like the dress, accessories and possessions.

Our life styles are reflected in our personalities and selfconcepts, same is the case with any consumer. We need to know what a life-style is made of. It is a person's mode of living as identified by his or her activities, interest and opinions. There is a method of measuring a consumer's lifestyle. This method is called as the psychographicswhich is the analysis technique used to measure consumer lifestyles- peoples activities, interests and opinions. Then based upon the combinations of these dimensions, consumers are classified (Bhasin. H, 2006).

Like the social class the human life cycle can have a significant impact on consumer behavior. The life cycle is an orderly series of stages in which consumer attitude and behavioral tendencies evolve and occur because of developing maturity, experience, income, and status. Marketers often define their target market in terms of the consumer's present lifecycle stage.

Marketing interest in the personality is based on the assumption that, in spite of their uniqueness as individuals, members of groups and aggregates may possess a given trait or type common with each other. Marketers therefore should not only consider the conscious, rational aspects of the products in developing appeal, but also consumers unconsciousness motives (Chowdhury. I, 2007).

Efforts to utilize personality theory as a single predictor item with consumer behavior have produced unconvincing results in general (Kassarjian and Sheffet, 1991). However, it is difficult to generalise about the effectiveness of personality in relation to predicting consumer's behavior and decision making process, because researchers have used a variety of competing theories, definitions, methodologies, and instruments measuring different personality characteristics, in a wider range of appropriate and inappropriate marketing applications (Pervin, 1997; Plummer, 2000). It is very difficult to provide a clear-cut assessment of whether personality as a single or general global construct is a good predictor of behavior without any other relevant information about the consumers, for example, demographic characteristics, attitudes, motives and values. The degree of construct specificity affects the level of relationships with consumer's behavior. Personality is considered to be very general construct, attitudes tends to be more of an intermediate level, and specific traits are more closely related with specific context and behavioral aspects of consumer's nature. Therefore, predictive validity of consumer's behavior varies according to the type of construct (broad, intermediate or specific) and the type of context the trait is hypothesized to be 
relevant and used for (Nakanishi, 1972; Kassarjian and Sheffet, 1991).

\subsection{Importance of Measuring Personality in Service and Product Industry}

Understanding the individual person in his or her role as a consumer should be a key issue in the study of consumer behavior, but in order to realize this vision the scope of personality research has to be broadened. (Baumgartner. H, 2002). In the area of service marketing customer's personality plays an important role. It is one of the important determinants in buying behavior. Marketers should always be concerned about the service related issues which directly affects the customer's attitude. Marketing spans many disciplines including mathematics, and psychology. Math plays an important role is predicting consumer behavior. Understanding the reasons behind consumer behavior requires knowledge of several theories of psychology. Consumer behavior is the study of how a consumer thinks, feels, and selects between competing products. In the service industry there are varieties of product lines. Different people go for different product lines. Like high class people generally go for highly priced products and on the other hand middle class people generally go for average priced products. So marketers therefore need to deliver message to their target customers based on their personality issues. Personality study may help marketers in making decisions regarding new product development, repositioning of existing products, creating advertising campaigns, as well as in understanding general pattern of consumer purchase behavior. Thus an understanding of what personality is, how it is organized, what functions it performs, how it can be measured and how a service marketer can change an existing attitude is very important for a service marketer to successfully combat competition.

\subsection{Relevant Earlier Researches}

Several researches have been conducted over the influences of personality traits in consumer buying behavior. Ranjbarian and Kia (2010) conducted a research on "The Influence of Personality Traits on Consideration Set Size" this study focused on the influence of five major personality traits (Big Five) on size of consumer's consideration set. The product involvement also was considered as a moderating variable in this relation. The results indicated that within the studied population, the Big Five has no significant effect on consideration set size. But cognitive dimension of product involvement was positive and direct relation with consideration set size.

Kaplan and Zarrilli (2000) have done a research on "The role of fragrance in the brand personality of consumer products". This study explored the role of fragrance in defining a brand's personality at the point of purchase relative to its packaging. Results contained herein were based on a consumer study of shampoo products designed to provide insight into recognizing fragrance's contribution to the marketing mix of consumer product goods, measuring the impact of fragrance on brand identity, and understanding how fragrance, along with packaging, influences consumers' purchase decisions and overall appeal.

G. Vani, M. Ganesh Babu, N. Panchanatham (2010) worked on "Toothpaste Brands -A Study of consumer behavior in Bangalore city". In this study they stressed the preference of consumers, and consumer awareness. Descriptive research design was adopted and the data is collected through primary and secondary sources. This study mainly focus on understanding the external factors like demographic, social, cultural ,price, quality ,product attributes for buying toothpaste. The market share of any product is highly determined by the purchasing behavior of the consumers.

In addition to this Little, Brian R. (1999) has conducted a research on "Personality and Motivation: Personal Action and the Cognitive Evolution". Deasy, Dorothy. (2000) have worked on "Express Brand Personality_Let Your Package Do the Talking." Both study focused on personality traits and how it affects consumer buying decision process. Soga, S., Shimai, S., and Otake, K. (2002) worked on "As analysis of the relationship between aggressiveness and personality traits of children."

\subsection{Significance of This Study From Earlier Word Wide Researches Contexts and Adding Value to Existing Literatures}

Service industry is one of the largest industries in Bangladesh. There are plenty of service related firms operating in our country. Their divisional branches are also established in the Khulna region. Huge numbers of customers are involved in the service industry buying goods and services in a regular basis. This study will basically focus on how customer's personality affects consumers buying decisions in the service industry. This study will measure the factors related to customer's personality and how it influences. With the help of this study service marketers can successfully position their products and services into their target market segments. This will help them to survive in the competition among the service industry. Besides in the social and economic perspective this study will also contribute. Our attitude towards the values, belief, and customs can be identified through this study. In addition to the service sector there are some other sectors where consumer's personality is an important factor to gain customer's satisfaction. For example: in the banking industry it will also be effective. By measuring personality traits bankers can successfully position their financial services to their target customers. This study will also help in some HR study e.g. HR branding where personality plays a significant role. Therefore we can say that this study will definitely 
contribute to the social and economic perspective in the country.

\section{Materials and Methods}

\subsection{Research Questions}

Research questions have been determined after reviewing the existing literature and also evaluating the contexts of local businesses and market set-up. In the process of setting the research questions -the prospective future contribution of this research work also has been considered. That was a major concern because the study should be able to contribute something in the existing scientific literatures and also for the development of the country and society. The following research questions have been set afterwards:

- Research Question 1: How personality affects consumer buying decision?

- Research Question 2: What can be done for eradicate those problems?

\subsection{Sub-Questions}

Sub-Questions of Research Question 1:

- What are the descriptive statistical outcomes of different available problems?

- What are the major problems areas under different problems?

- What is co-relation among different problem areas?

- What is the condition of the factors among different problems?

Sub-Questions of Research Question 2:

- What service organizations can do?

- What customers themselves can do?

\subsection{Research Design}

In order to solve the above mentioned research questions and corresponding sub-questions this study has been adopted the following research design comprising data collection and analysis. This study has utilized survey research methodology. A highly structured questionnaire was developed based on discussions with selected university faculty, and authority of print media and literature review. The pre-test was conducted by trained graduate students for wording, layout, content validity, and determining main data collection methods. Those students were the bachelor students of the Business Administration Department of Khulna University, Bangladesh. They were involved both in pre-testing the questionnaire and also in data collection campaign. They were provided with adequate training before taking their part in the research campaign. Those training have given them necessary idea about the questionnaire and also how to conduct an interview with questionnaire with different tour operators. University faculty of Business Administration Department, Khulna University; who are expert in research and data collection has provided them the training prior to the data collection.

\subsection{The Population}

The population of this study is all customers who regularly purchase consumer goods in the Khulna region.

\subsection{Sampling Design}

A total of 150 customers from the population sectors have been selected with following the simple random sampling procedure. Sample size has been selected after reviewing a lot of literature and study conducted on similar field. The accuracy of representation also been assured from the evidences of those earlier researches. A total of 150 customers have taken part in interview with structured questionnaire.

\subsection{Instrument Development}

Questionnaire: Research conduction with the help of questionnaire is the most popular method irrespective of the sectors. It is used in almost every field and business sector is no exception. This study will deal with the problems of personality affecting consumer buying decision in the Khulna region. The research design of the study elaborates that the constraints were identified from the responses of the customers, as they know the best about the problems in personality they normally and frequently faced while purchasing. For serving that purpose it is always require preparing a structured questionnaire. The questionnaire for the study was prepared on the basis of literatures review and context of the region. Since it is the comparison between two theories of personality there are two questionnaires for this study. It consists of total 43 questions of 9 concerning variables in the form of variety of factors affecting personality e.g. ethnocentrism, dogmatism, compulsiveness, social character, need for uniqueness, consumer innovativeness, compliant, detached and aggressive. It will be prepared by using a five-point Likert scale $(1=$ strongly disagree and $5=$ strongly agree $)$.

\subsection{Data Collection}

The process of gathering information by trainees was facilitated through a face to face interview of the tour operators. Bachelor Students of Business Administration Discipline of Khulna University was took part in the survey conduction. One month starting from mid of September to mid November 2011 was taken for survey conduction and data collection. Apart from that a lot of secondary data will also be collected from different published sources.

\subsection{Data Analysis}

The data analysis has been done by utilizing both quantitative and qualitative analysis techniques. This study has conducted the data analysis with the application of SPSS software version 15.0. Data has been analyzed with 
the help of the literatures of the previous researches of the same field. In order to make the analysis fruitful and goal directed special attention has been given towards fulfilling all the research questions and sub-questions successfully by the process of data analysis. The following four research questions and their corresponding sub questions will be analyzed by utilizing the following respective data analysis techniques:

- Research Question 1: How personality affects consumer buying decision?

- Sub-Questions:

Sub-Questions of Research Question 1:

- What are the descriptive statistical outcomes of different available problems?

- What are the major problems areas under different problems?

- What is co-relation among different problem areas?

- What is the condition of the factors among different problems?

In order to fulfill the first research question and its subquestions: first the outcome of the survey was tabulated. The mean, standard deviation and coefficient of variation scores of the 9 major problem variables was analyzed from the tabular presentation. Then factor analysis was done with the principal component analysis. The 9 independent variables of the study were generated relevant items from the two questionnaires survey and those were being purified and validated through the factor analysis and internal consistency. The Verimax rotation procedure and Eigen value plot has been utilized to identify the number of components. From the gross outcome the ranking of the 9 constraints was taken place from the mean score. Along with that the correlation were also identified with using bivariate analysis among the variables of all the constraints dimension. The major problems have been analyzed by utilizing qualitative analysis techniques by utilizing the response of the tour operators. It was done with the assistance of a number of studies in this field.

- Research Question 2: What can be done for eradicate those problems?

- Sub-Questions of Research Question 2:

- What service organizations can do?

- What customers themselves can do?

In order to fulfill the requirements of the research question 2 and it's corresponding sub-questions-descriptive and qualitative analysis has been done for suggesting the improving ways for service organizations. In order to do so the problem detection and extremity as well as the factor outputs were also considered and thus assisted a lot for the problem eradication suggestion process. In addition the policies as well as measures taken by different region of the globe for boosting the tourism sector by eliminating problems of the tour operators will also be evaluated.

\subsection{Measurement of Variables}

The survey questionnaire has measured 9 constraints variables. The effect of the personality in buying consumer goods in Khulna city has been evaluated by those 9 variables in the form of: ethnocentrism, dogmatism, compulsiveness, social character, and need for uniqueness, consumer innovativeness, compliant, detached and aggressive. Here, the customer's personality problem in Khulna region is the dependent variable and those 9 constraints are the independent variables. The relationship of the variables was evaluated by the survey outcomes.

\section{Data Analysis and Interpretation: Neo-Freudian and Trait Theory}

\subsection{Complaint}

From the analysis of descriptive statistics we have found that the obtained mean of the dimension compliant is 3.3425. The highest mean has been obtained as 3.57 in case of sharing opinion before any purchase which is very influential factor in personality. The overall outcome has found that factors are influential. The standard deviation score of 0.946 is high that means the variability among the dimension is spread widely. The correlation matrix in this dimension shows hundred percent positive correlations among the entire questions variable and all the four questions of this dimension have internal consistent relationship and also relationship has been derived in the responses of the buying behavior. There is a high degree of correlation between sharing opinion before any purchase and Getting benefited by consulting with friends. Variance analysis clearly shows first two questions of the dimension covers $83.409 \%$ of the total variance. That represent that the first two questions are of great importance among all the questions of the dimensions. [Insert Table 3,4 and 5 here]

\subsection{Detached}

Descriptive statistics shows that the obtained mean of the dimension detached is 3.208 which are moderate. The highest mean has been obtained as 3.57 in case of sharing opinion before any purchase which is very influential factor in personality. The standard deviation score of 0.9162 is high that means the variability among the dimension is spread widely. The correlation matrix in this dimension shows hundred percent positive correlations among the entire questions variable and all the five questions of this dimension have internal consistent relationship and also relationship has been derived in the responses of the buying behavior. There is a high degree of correlation between perfect at purchasing and people appreciate my own purchasing. Variance analysis clearly shows first three questions of the dimension covers $83.202 \%$ of the total variance. That represent that the first three questions are of great importance among all the questions of the dimensions. [Insert Table 6, 7 and 8 Here]. 


\subsection{Aggressive}

Descriptive statistics shows that the obtained mean of the dimension aggressive is 3.248 which are moderate. The highest mean has been obtained as 3.90 in case of products and prestige which is very powerful factor in personality. The standard deviation score of 0.8904 is high that means the variability among the dimension is spread widely. The correlation matrix in this dimension shows both negative and positive correlation between the variables. There is a high degree of correlation between purchasing luxurious products and Counterparts as competitors. There is high degree of negative correlation between purchase based on emotion and products and prestige. Variance analysis clearly shows first three questions of the dimension covers $75.793 \%$ of the total variance. That represent that the first three questions are of great importance among all the questions of the dimensions. [Insert Table 9, 10 and 11 Here].

\subsection{Ethnocentrism}

From the analysis of descriptive statistics we can see that the obtained mean of the dimension ethnocentrism is 3.302 . The highest mean has been obtained as 3.89 in case of buying home products keep home working which is a very dominant factor in personality. The overall outcome has found that factors are influential. The standard deviation score of 0.9516 is high that means the variability among the dimension is spread widely. The correlation matrix in this dimension shows both negative and positive correlation between the variables. There is a high degree of correlation between higher tax on foreign products to enter home country and restrictions on all imports. There is also negative correlation between restrictions on all imports and importing of unavailable products. Variance analysis clearly shows first three questions of the dimension covers $83.824 \%$ of the total variance. That represent that the first three questions are of great importance among all the questions of the dimensions. [Insert Table 12, 13 and 14 Here].

\subsection{Compulsiveness}

Descriptive statistics shows that the obtained mean of the dimension compulsiveness is 2.662 which are pretty much lower. The highest mean has been obtained as 2.97 in case of buying something to make oneself feel better which is very significant factor in personality. The standard deviation score of 1.1508 is high that means the variability among the dimension is spread widely. The correlation matrix in this dimension shows hundred percent positive correlations among the entire questions variable and all the five questions of this dimension have internal consistent relationship and also relationship has been derived in the responses of the buying behavior. There is a high degree of positive correlation between buying irrelevant products and buying products which can't afford. Variance analysis clearly shows first two questions of the dimension covers $82.252 \%$ of the total variance. That represent that the first two questions are of great importance among all the questions of the dimensions. [Insert Table 15, 16 and 17 here].

\subsection{Dogmatism}

From the analysis of descriptive statistics we can see that the obtained mean of the dimension dogmatism is 3.705 . The highest mean has been obtained as 4.21 in case of new products and diversification which is a very dominant factor in personality. The overall outcome has found that factors are influential. The standard deviation score of 0.70675 is high that means the variability among the dimension is spread widely. The correlation matrix in this dimension shows both negative and positive correlation between the variables. There is a high degree of correlation between new products and diversification and Accepting new products. There is also negative correlation between buying similar products and accepting new products. Variance analysis clearly shows first two questions of the dimension covers $70.483 \%$ of the total variance. That represent that the first two questions are of great importance among all the questions of the dimensions. [Insert Table 18, 19 and 20 Here].

\subsection{Social Character}

From the analysis of descriptive statistics we can see that the obtained mean of the dimension social character is 3.308. The highest mean has been obtained as 3.46 in case of purchasing and belief which is a very leading factor in personality. The overall outcome has found that factors are influential. The standard deviation score of 0.9116 is high that means the variability among the dimension is spread widely. The correlation matrix in this dimension shows both negative and positive correlation between the variables. There is a high degree of correlation between benefit from other's advice and Inviting friends while purchasing. There is also high degree of negative correlation between benefit from other's advice and others opinion and confusion. Variance analysis clearly shows first three questions of the dimension covers $84.545 \%$ of the total variance. That represent that the first three questions are of great importance among all the questions of the dimensions. [Insert Table 21, 22 and 23 Here].

\subsection{Need for Uniqueness}

Descriptive statistics shows that the obtained mean of the dimension need for uniqueness is 2.796 which are pretty much lower. The highest mean has been obtained as 3.01 in case of losing interest on popular products which is very significant factor in personality. The standard deviation score of 1.1352 is high that means the variability among the dimension is spread widely. The correlation matrix in this dimension shows hundred percent positive correlations 
among the entire questions variable and all the five questions of this dimension have internal consistent relationship and also relationship has been derived in the responses of the buying behavior. There is a high degree of positive correlation between avoiding accepted products and losing interest on popular products. Variance analysis clearly shows first three questions of the dimension covers $86.011 \%$ of the total variance. That represent that the first three questions are of great importance among all the questions of the dimensions. [Insert Table 24, 25 and 26 Here].

\subsection{Consumer Innovativeness}

From the analysis of descriptive statistics we can see that the obtained mean of the dimension consumer innovativeness is 3.162. The highest mean has been obtained as 3.65 in case of purchasing a brand new product which is a very leading factor in personality. The standard deviation score of 1.0384 is high that means the variability among the dimension is spread widely. The correlation matrix in this dimension shows both negative and positive correlation between the variables. There is a high degree of correlation between enjoying buying unfamiliar products and purchasing a brand new product. There is also high degree of negative correlation between purchasing familiar products and enjoying buying unfamiliar products. Variance analysis clearly shows first three questions of the dimension covers $85.383 \%$ of the total variance. That represent that the first three questions are of great importance among all the questions of the dimensions. [Insert Table 27, 28 and 29 Here].

\section{Findings and Analysis: Comparison between Neo-Freudian Theory and Trait Theory}

The dimensions of both neo-Freudian theory and trait theory have been analyzed by measuring mean, standard deviation, correlation and component matrix. This is done by the SPSS for windows software to find out the outcomes and to compare the outcomes of these two theories.

There were three dimensions under Neo-Freudian theory, each of them has been considered in calculating the outcomes. Each of three dimensions showed different outcomes.

- Firstly Compliant dimension: The mean score of this dimension is of 3.3425 , standard deviation is 0.946 , correlation is hundred percent positive. [Insert Table 3 and 4 here].

- Secondly Detached dimension: The mean score of this dimension is of 3.208 , standard deviation is 0.9162 , correlation is hundred percent positive. [Insert Table 6 and 7 here].

- Thirdly Aggressive dimension: The mean score of this dimension is of 3.248 , standard deviation is 0.8904 , correlation is hundred percent positive. [Insert Table 9 and 10 here].

Among three dimensions of the Neo-Freudian theory mean value of all these dimensions are nearly same and all are influential factors in creating personality problems in purchasing decision. Because the mean score of each of the three dimensions is above 3.00 that indicates that customer are influenced by personality under this dimension. The overall variability is more or less same because the standard deviation of each of the dimension is very much similar. The standard deviation is between .80-.94 which indicates a high variability among the variables. There were six dimensions under trait theory, each of them has been considered in calculating the outcomes. Each of four dimensions showed different outcomes.

- Firstly Ethnocentrism dimension: The mean score of this dimension is of 3.302, standard deviation is 0.9516 , and correlation is both positive and negative. [Insert Table 12 and 13 here].

- Secondly Compulsiveness dimension: The mean score of this dimension is of 2.662 , standard deviation is 1.1508 , and correlation is hundred percent positive. [Insert Table 15 and 16 here].

- Thirdly Dogmatism dimension: The mean score of this dimension is of 3.705 , standard deviation is 0.70675 , and correlation is both positive and negative. [Insert Table 18 and 19 here].

- Fourthly Social Character dimension: The mean score of this dimension is of 3.308, standard deviation is 0.9116 , and correlation is both positive and negative. [Insert Table 21 and 22 here].

- Fifthly Need for Uniqueness dimension: The mean score of this dimension is of 2.796 , standard deviation is 1.1352 , and correlation is hundred percent positive. [Insert Table 24 and 25 here].

Finally Consumer Innovativeness dimension: The mean score of this dimension is of 3.162 , standard deviation is 1.0384, and correlation is both positive and negative. [Insert Table 27 and 28 here].

Among the dimensions of trait theory four of the dimensions are found to be influential in creating personality problem in consumer purchasing decision. The other two factors are not that much dominant than that of those four. The variability among the answers of the respective questions is also high because each of the dimensions showed the standard deviation above 0.80 . The variability is roughly same among the questions of the both theories. But the dominant level is largely different from each other. Among three dimensions of neo-Freudian theory, all showed mean of more than 3.00. Trait theory, one the other hand, showed four of the six dimensions' mean is above 3.00 . The other two dimensions are below 3.00 .

From the overall analysis of mean and standard deviations we have found that: 


\section{Conclusion and Recommendations}

\subsection{Conclusion}

Measuring customer's attitude has become an important phenomenon in the service industry. Consumer goods as a service industry should deliver quality services so that customers are satisfied and have positive attitudes towards the services. Personality plays a significant role in the consumer buying behavior since different consumers have different personality traits which reflect their buying behavior. The study was conducted in the Khulna metropolitan area to find out the factors of personality metropolitan area to find out the factors of personality.

Table 1. Mean value of factors-Neo-Freudian theory

\begin{tabular}{ccc}
\hline Dimensions & Mean & Standard Deviation \\
\hline Compliant & 3.3425 & 0.946 \\
Detached & 3.208 & 0.9162 \\
Aggressive & 3.248 & 0.8904 \\
Average & 3.266167 & 0.917533 \\
\hline
\end{tabular}

Table 2. Mean value of the factors-Trait theory

\begin{tabular}{ccc}
\hline Dimensions & Mean & Standard Deviation \\
\hline Ethnocentrism & 3.302 & 0.9516 \\
Compulsiveness & 2.662 & 1.1508 \\
Dogmatism & 3.705 & 0.70675 \\
Social Character & 3.308 & 0.9116 \\
Need for Uniqueness & 2.796 & 1.1352 \\
Consumer Innovativeness & 3.162 & 1.0384 \\
Average & 3.155833 & 0.982392 \\
\hline
\end{tabular}

affecting consumers buying behavior. The results of this study illustrated that some factors e.g. compliant, detached and aggressive for neo-Freudian theory and ethnocentrism, dogmatism for trait theory are very much responsible for creating personality problem among the customers. The study also suggested some of the strategies by how a service organization can remove these kinds of problems and survive in the competition. With the rapid growing competition among service, the expectation of the customers has immensely increased. The study thus will help the service marketers to find out the dominant factors that creates personality problems and take necessary precautions to remove those problems.

\subsection{Recommendation}

After analyzing the outcome of the survey analysis the study has recommended some of the strategies which might be effective in reducing personality problems in consumer buying behavior. These are:

- First of all marketers should categorize their markets based on different personality traits that consumers belong to. This will help them to develop products which will suit their personality traits.

- Consumers seeking for uniqueness should be provided with goods and services that reflect something differences or which is rare.

- Those who are ethnocentric should be delivered with goods and services that might

- Higher dogmatic persons tend to be more receptive to ads for new products. Here marketers might use celebrity to promote their products.

- Inner-directed and other-directed customers are attracted to different types of promotional messages. Inner directed people tend to prefer ads that focus on personal benefit and other directed persons tend to find ads which focus on social acceptance. Thus marketers should develop their promotional messages in such a way so that both can accept the services.

- Finally service organization should invest more on research and development which will ultimately help them to find out what customers want and based on their preferences marketers can make necessary changes to their goods and services.

\section{Appendix}

\subsection{Neo-Freudian Theory}

\subsubsection{Compliant}

Table 3. Descriptive Statistics of compliant

\begin{tabular}{llllll}
\hline & N & Minimum & Maximum & Mean & Std. Deviation \\
\hline Talking prior to purchase & 150 & 1 & 5 & 3.32 & 1.101 \\
Getting benefit by consulting with friends & 150 & 1 & 5 & 3.45 & .901 \\
People should share opinion before any purchase & 150 & 1 & 5 & 3.57 & .878 \\
Moving towards others prior to any purchase & 150 & 1 & 5 & 3.03 & .904 \\
Valid N (list wise) & 150 & & 3.3425 & 0.946 \\
\hline
\end{tabular}


Table 4. Correlations co-efficient of compliant

\begin{tabular}{|c|c|c|c|c|c|}
\hline & & $\begin{array}{l}\text { Talking prior to } \\
\text { purchase }\end{array}$ & $\begin{array}{l}\text { Getting benefitted by } \\
\text { consulting with friends }\end{array}$ & $\begin{array}{l}\text { sharing opinion } \\
\text { before any purchase }\end{array}$ & $\begin{array}{l}\text { Moving towards others } \\
\text { prior to any purchase }\end{array}$ \\
\hline \multirow[t]{3}{*}{ Talking prior to purchase } & $\begin{array}{l}\text { Pearson } \\
\text { Correlation }\end{array}$ & 1 & $.606(* *)$ & $.644(* *)$ & $.618(* *)$ \\
\hline & Sig. (2-tailed) & & .000 & .000 & .000 \\
\hline & $\mathrm{N}$ & 150 & 150 & 150 & 150 \\
\hline \multirow[t]{2}{*}{$\begin{array}{l}\text { Getting benefitted by } \\
\text { consulting with friends }\end{array}$} & $\begin{array}{l}\text { Pearson } \\
\text { Correlation }\end{array}$ & $.606(* *)$ & 1 & $.687(* *)$ & $.562(* *)$ \\
\hline & $\begin{array}{l}\text { Sig. (2-tailed) } \\
\mathrm{N}\end{array}$ & $\begin{array}{l}.000 \\
150\end{array}$ & 150 & $\begin{array}{l}.000 \\
150\end{array}$ & $\begin{array}{l}.000 \\
150\end{array}$ \\
\hline \multirow[t]{2}{*}{$\begin{array}{l}\text { Sharing opinion before } \\
\text { any purchase }\end{array}$} & $\begin{array}{l}\text { Pearson } \\
\text { Correlation }\end{array}$ & $.644(* *)$ & $.687(* *)$ & 1 & $.513(* *)$ \\
\hline & $\begin{array}{l}\text { Sig. (2-tailed) } \\
\mathrm{N}\end{array}$ & $\begin{array}{l}.000 \\
150\end{array}$ & $\begin{array}{l}.000 \\
150\end{array}$ & 150 & $\begin{array}{l}.000 \\
150\end{array}$ \\
\hline \multirow[t]{2}{*}{$\begin{array}{l}\text { Moving towards others } \\
\text { prior to any purchase }\end{array}$} & $\begin{array}{l}\text { Pearson } \\
\text { Correlation }\end{array}$ & $.618(* *)$ & $.562(* *)$ & $.513(* *)$ & 1 \\
\hline & $\begin{array}{l}\text { Sig. (2-tailed) } \\
\mathrm{N}\end{array}$ & $\begin{array}{l}.000 \\
150\end{array}$ & $\begin{array}{l}.000 \\
150\end{array}$ & $\begin{array}{l}.000 \\
150\end{array}$ & 150 \\
\hline
\end{tabular}

** Correlation is significant at the 0.01 level (2-tailed).

Table 5. Total Variance Explained-compliant

\begin{tabular}{lcccccc}
\hline Component & \multicolumn{3}{c}{ Initial Eigen values } & \multicolumn{3}{c}{ Extraction Sums of Squared Loadings } \\
\% of Variance & Cumulative \% \\
\hline 1 & Total & \% of Variance & Cumulative \% & Total & 70.430 \\
2 & 2.817 & 70.430 & 70.430 & 2.817 & 70.430 & \\
3 & .519 & 12.979 & 83.409 & & & \\
4 & .375 & 9.387 & 92.795 & & & \\
\hline
\end{tabular}

Extraction Method: Principal Component Analysis.

\subsubsection{Detached}

Table 6. Descriptive Statistics of Detached

\begin{tabular}{|c|c|c|c|c|c|}
\hline & $\mathbf{N}$ & Minimum & Maximum & Mean & Std. Deviation \\
\hline Purchase based on own evaluation & 150 & 1 & 5 & 3.50 & 1.002 \\
\hline Talking with others as time killing & 150 & 1 & 5 & 2.45 & .994 \\
\hline Hardly belief other's opinion before purchase & 150 & 1 & 5 & 2.77 & .921 \\
\hline People appreciate my own purchasing & 150 & 2 & 5 & 3.76 & .748 \\
\hline Perfect at purchasing & 150 & 1 & 5 & 3.56 & .916 \\
\hline Valid N (list wise) & 150 & & & 3.208 & 0.9162 \\
\hline
\end{tabular}

Table 7. Correlations co-efficient of Detached

\begin{tabular}{|c|c|c|c|c|c|c|}
\hline & & $\begin{array}{l}\text { Purchase based } \\
\text { on own evaluation }\end{array}$ & $\begin{array}{l}\text { Talking with } \\
\text { others as time } \\
\text { killing }\end{array}$ & $\begin{array}{l}\text { Hardly belief other's } \\
\text { opinion } \\
\text { purchase }\end{array}$ & $\begin{array}{l}\text { People appreciate } \\
\text { my own purchasing }\end{array}$ & $\begin{array}{l}\text { Perfect at } \\
\text { purchasing }\end{array}$ \\
\hline \multirow[t]{2}{*}{$\begin{array}{l}\text { Purchase based on } \\
\text { own evaluation }\end{array}$} & $\begin{array}{l}\text { Pearson } \\
\text { Correlation }\end{array}$ & 1 & $.533(* *)$ & $.480(* *)$ & .152 & $.322(* *)$ \\
\hline & $\begin{array}{l}\text { Sig. (2-tailed) } \\
\mathrm{N}\end{array}$ & 150 & $\begin{array}{l}.000 \\
150\end{array}$ & $\begin{array}{l}.000 \\
150\end{array}$ & $\begin{array}{l}.063 \\
150\end{array}$ & $\begin{array}{l}.000 \\
150\end{array}$ \\
\hline \multirow[t]{3}{*}{$\begin{array}{l}\text { Talking with others as } \\
\text { time killing }\end{array}$} & $\begin{array}{l}\text { Pearson } \\
\text { Correlation }\end{array}$ & $.533(* *)$ & 1 & $.399(* *)$ & $.165(*)$ & $.316(* *)$ \\
\hline & Sig. (2-tailed) & .000 & . & .000 & .043 & .000 \\
\hline & $\mathrm{N}$ & 150 & 150 & 150 & 150 & 150 \\
\hline \multirow[t]{2}{*}{$\begin{array}{l}\text { Hardly belief } \\
\begin{array}{ll}\text { opinion } & \text { before } \\
\text { purchase } & \end{array}\end{array}$} & $\begin{array}{l}\text { Pearson } \\
\text { Correlation }\end{array}$ & $.480(* *)$ & $.399(* *)$ & 1 & $.232(* *)$ & $.406(* *)$ \\
\hline & Sig. (2-tailed) & .000 & .000 & & .004 & .000 \\
\hline
\end{tabular}




\begin{tabular}{|c|c|c|c|c|c|c|}
\hline \multirow{3}{*}{$\begin{array}{l}\text { People appreciate my } \\
\text { own purchasing }\end{array}$} & $\mathrm{N}$ & 150 & 150 & 150 & 150 & 150 \\
\hline & $\begin{array}{l}\text { Pearson } \\
\text { Correlation }\end{array}$ & .152 & $.165(*)$ & $.232(* *)$ & 1 & $.570(* *)$ \\
\hline & $\begin{array}{l}\text { Sig. (2-tailed) } \\
\mathrm{N}\end{array}$ & $\begin{array}{l}.063 \\
150\end{array}$ & $\begin{array}{l}.043 \\
150\end{array}$ & $\begin{array}{l}.004 \\
150\end{array}$ & 150 & $\begin{array}{l}.000 \\
150\end{array}$ \\
\hline \multirow[t]{2}{*}{ Perfect at purchasing } & $\begin{array}{l}\text { Pearson } \\
\text { Correlation }\end{array}$ & $.322(* *)$ & $.316(* *)$ & $.406(* *)$ & $.570(* *)$ & 1 \\
\hline & Sig. (2-tailed) & $\begin{array}{l}.000 \\
150\end{array}$ & $\begin{array}{l}.000 \\
150\end{array}$ & $\begin{array}{l}.000 \\
150\end{array}$ & .000 & 150 \\
\hline
\end{tabular}

** Correlation is significant at the 0.01 level (2-tailed). * Correlation is significant at the 0.05 level (2-tailed).

Table 8. Total Variance Explained-Detached

\begin{tabular}{lllllll}
\hline Component & \multicolumn{3}{l}{ Initial Eigen values } & & \multicolumn{3}{l}{ Extraction Sums of Squared Loadings } \\
& Total & \% of Variance & Cumulative \% & Total & \% of Variance & Cumulative \% \\
\hline 1 & 2.446 & 48.923 & 48.923 & 2.446 & 48.923 & 48.923 \\
2 & 1.119 & 22.372 & 71.295 & 1.119 & 22.372 & 71.295 \\
3 & .595 & 11.908 & 83.202 & & & \\
4 & .447 & 8.947 & 92.149 & & & \\
5 & .393 & 7.851 & 100.000 & & & \\
\hline
\end{tabular}

Extraction Method: Principal Component Analysis.

\subsubsection{Aggressive}

Table 9. Descriptive Statistics of Aggressive

\begin{tabular}{|c|c|c|c|c|c|}
\hline & $\mathbf{N}$ & Minimum & Maximum & Mean & Std. Deviation \\
\hline Products and prestige & 150 & 1 & 5 & 3.90 & .817 \\
\hline Purchase appreciated by others & 150 & 1 & 5 & 3.72 & .725 \\
\hline Purchase based on emotion & 150 & 1 & 5 & 2.86 & 1.023 \\
\hline Purchasing luxurious products & 150 & 1 & 5 & 3.15 & .878 \\
\hline Counterparts as competitors & 150 & 1 & 5 & 2.61 & 1.009 \\
\hline Valid N (list wise) & 150 & & & 3.248 & 0.8904 \\
\hline
\end{tabular}

Table 10. Correlations co-efficient of Aggressive

\begin{tabular}{|c|c|c|c|c|c|c|c|}
\hline & & $\begin{array}{l}\text { Products and } \\
\text { prestige }\end{array}$ & $\begin{array}{l}\text { Purchase } \\
\text { appreciated } \\
\text { others }\end{array}$ & by & $\begin{array}{l}\text { Purchase based } \\
\text { on emotion }\end{array}$ & $\begin{array}{l}\text { Purchasing } \\
\text { luxurious products }\end{array}$ & $\begin{array}{l}\text { Counterparts } \\
\text { competitors }\end{array}$ \\
\hline \multirow[t]{3}{*}{$\begin{array}{l}\text { Products } \\
\text { prestige }\end{array}$} & $\begin{array}{l}\text { Pearson } \\
\text { Correlation }\end{array}$ & 1 & $.190\left(^{*}\right)$ & & $-.226(* *)$ & $.367(* *)$ & $.245(* *)$ \\
\hline & Sig. (2-tailed) & & .020 & & .006 & .000 & .003 \\
\hline & $\mathrm{N}$ & 150 & 150 & & 150 & 150 & 150 \\
\hline \multirow[t]{2}{*}{$\begin{array}{l}\text { Purchase } \\
\text { appreciated } \\
\text { others }\end{array}$} & $\begin{array}{l}\text { Pearson } \\
\text { Correlation }\end{array}$ & $.190\left(^{*}\right)$ & 1 & & -.144 & $.202(*)$ & .032 \\
\hline & $\begin{array}{l}\text { Sig. (2-tailed) } \\
\mathrm{N}\end{array}$ & $\begin{array}{l}.020 \\
150\end{array}$ & 150 & & $\begin{array}{l}.079 \\
150\end{array}$ & $\begin{array}{l}.013 \\
150\end{array}$ & $\begin{array}{l}.698 \\
150\end{array}$ \\
\hline \multirow[t]{2}{*}{$\begin{array}{l}\text { Purchase based on } \\
\text { emotion }\end{array}$} & $\begin{array}{l}\text { Pearson } \\
\text { Correlation }\end{array}$ & $-.226(* *)$ & -.144 & & 1 & -.134 & -.106 \\
\hline & $\begin{array}{l}\text { Sig. (2-tailed) } \\
\mathrm{N}\end{array}$ & $\begin{array}{l}.006 \\
150\end{array}$ & $\begin{array}{l}.079 \\
150\end{array}$ & & 150 & $\begin{array}{l}.102 \\
150\end{array}$ & $\begin{array}{l}.198 \\
150\end{array}$ \\
\hline \multirow[t]{2}{*}{$\begin{array}{l}\text { Purchasing } \\
\text { luxurious products. }\end{array}$} & $\begin{array}{l}\text { Pearson } \\
\text { Correlation }\end{array}$ & $.367(* *)$ & $.202(*)$ & & -.134 & 1 & $.437(* *)$ \\
\hline & $\begin{array}{l}\text { Sig. (2-tailed) } \\
\mathrm{N}\end{array}$ & $\begin{array}{l}.000 \\
150\end{array}$ & $\begin{array}{l}.013 \\
150\end{array}$ & & $\begin{array}{l}.102 \\
150\end{array}$ & 150 & $\begin{array}{l}.000 \\
150\end{array}$ \\
\hline \multirow[t]{2}{*}{$\begin{array}{l}\text { Counterparts } \\
\text { competitors }\end{array}$} & $\begin{array}{l}\text { Pearson } \\
\text { Correlation }\end{array}$ & $.245(* *)$ & .032 & & -.106 & $.437(* *)$ & 1 \\
\hline & $\begin{array}{l}\text { Sig. (2-tailed) } \\
\mathrm{N}\end{array}$ & $\begin{array}{l}.003 \\
150\end{array}$ & $\begin{array}{l}.698 \\
150\end{array}$ & & $\begin{array}{l}.198 \\
150\end{array}$ & $\begin{array}{l}.000 \\
150\end{array}$ & 150 \\
\hline
\end{tabular}

* Correlation is significant at the 0.05 level (2-tailed). ** Correlation is significant at the 0.01 level (2-tailed). 
Table 11. Total Variance Explained-Aggressive

\begin{tabular}{llllll}
\hline \multirow{2}{*}{ Component } & \multicolumn{2}{l}{ Initial Eigen values } & & \multicolumn{2}{c}{ Extraction Sums of Squared Loadings } \\
Total & \% of Variance & Cumulative \% & Total & \% of Variance & Cumulative \% \\
\hline 1 & 1.885 & 37.692 & 37.692 & 1.885 & 37.692 \\
2 & 1.034 & 20.677 & 58.369 & 1.034 & 20.677 \\
3 & .871 & 17.424 & 75.793 & & \\
4 & .695 & 13.901 & 89.694 & & \\
5 & .515 & 10.306 & 100.000 & & \\
\hline
\end{tabular}

Extraction Method: Principal Component Analysis.

\subsection{Trait Theory}

\subsubsection{Ethnocentrism}

Table 12. Descriptive Statistics of ethnocentrism

\begin{tabular}{|c|c|c|c|c|c|}
\hline & $\mathbf{N}$ & Minimum & Maximum & Mean & Std. Deviation \\
\hline Purchase home made products only & 150 & 1 & 5 & 2.37 & .965 \\
\hline Restrictions on all imports. & 150 & 1 & 5 & 3.18 & 1.100 \\
\hline Higher tax on foreign products to enter home country & 150 & 1 & 5 & 3.53 & 1.001 \\
\hline Buying home products keep home working. & 150 & 1 & 5 & 3.89 & .761 \\
\hline Importing of unavailable products & 150 & 1 & 5 & 3.54 & .931 \\
\hline Valid N (list wise) & 150 & & & 3.302 & 0.9516 \\
\hline
\end{tabular}

Table 13. Correlations co-efficient of ethnocentrism

\begin{tabular}{|c|c|c|c|c|c|c|}
\hline & & $\begin{array}{l}\text { Purchase home } \\
\text { made products } \\
\text { only }\end{array}$ & $\begin{array}{l}\text { Restrictions on } \\
\text { all imports }\end{array}$ & $\begin{array}{l}\text { Higher tax on } \\
\text { foreign products to } \\
\text { enter home country }\end{array}$ & $\begin{array}{lr}\text { Buying } & \text { home } \\
\text { products } & \text { keep } \\
\text { home working. }\end{array}$ & $\begin{array}{l}\text { Importing } \\
\text { unavailable } \\
\text { products } \\
\end{array}$ \\
\hline \multirow[t]{3}{*}{$\begin{array}{l}\text { Purchase home made } \\
\text { products only }\end{array}$} & $\begin{array}{l}\text { Pearson } \\
\text { Correlation }\end{array}$ & 1 & $.525(* *)$ & $.382(* *)$ & $.364(* *)$ & .054 \\
\hline & $\begin{array}{l}\text { Sig. } \\
\text { tailed })\end{array}$ & . & .000 & .000 & .000 & .508 \\
\hline & $\mathrm{N}$ & 150 & 150 & 150 & 150 & 150 \\
\hline \multirow[t]{3}{*}{$\begin{array}{l}\text { Restrictions } \\
\text { imports }\end{array}$} & $\begin{array}{l}\text { Pearson } \\
\text { Correlation }\end{array}$ & $.525(* *)$ & 1 & $.627(* *)$ & $.280(* *)$ & -.023 \\
\hline & $\begin{array}{l}\text { Sig. } \\
\text { tailed })\end{array}$ & .000 & . & .000 & .001 & .776 \\
\hline & $\mathrm{N}$ & 150 & 150 & 150 & 150 & 150 \\
\hline \multirow[t]{3}{*}{$\begin{array}{l}\text { Higher tax on foreign } \\
\text { products to enter home } \\
\text { country }\end{array}$} & $\begin{array}{l}\text { Pearson } \\
\text { Correlation }\end{array}$ & $.382(* *)$ & $.627(* *)$ & 1 & $.347(* *)$ & $.161(*)$ \\
\hline & $\begin{array}{l}\text { Sig. } \\
\text { tailed) }\end{array}$ & .000 & .000 & . & .000 & .049 \\
\hline & $\mathrm{N}$ & 150 & 150 & 150 & 150 & 150 \\
\hline \multirow[t]{3}{*}{$\begin{array}{l}\text { Buying home products } \\
\text { keep home working. }\end{array}$} & $\begin{array}{l}\text { Pearson } \\
\text { Correlation }\end{array}$ & $.364(* *)$ & $.280(* *)$ & $.347(* *)$ & 1 & $.394(* *)$ \\
\hline & $\begin{array}{l}\text { Sig. } \\
\text { tailed) }\end{array}$ & .000 & .001 & .000 & . & .000 \\
\hline & $\mathrm{N}$ & 150 & 150 & 150 & 150 & 150 \\
\hline \multirow[t]{3}{*}{$\begin{array}{l}\text { Importing of } \\
\text { unavailable products }\end{array}$} & $\begin{array}{l}\text { Pearson } \\
\text { Correlation }\end{array}$ & .054 & -.023 & $.161(*)$ & $.394(* *)$ & 1 \\
\hline & $\begin{array}{l}\text { Sig. } \\
\text { tailed) }\end{array}$ & .508 & .776 & .049 & .000 & . \\
\hline & $\mathrm{N}$ & 150 & 150 & 150 & 150 & 150 \\
\hline
\end{tabular}

** Correlation is significant at the 0.01 level (2-tailed). * Correlation is significant at the 0.05 level (2-tailed).

Table 14. Total Variance Explained-ethnocentrism

\begin{tabular}{|c|c|c|c|c|c|c|}
\hline \multirow[t]{2}{*}{ Component } & \multicolumn{3}{|c|}{ Initial Eigen values } & \multicolumn{3}{|c|}{ Extraction Sums of Squared Loadings } \\
\hline & Total & $\%$ of Variance & Cumulative \% & Total & $\%$ of Variance & Cumulative \% \\
\hline 1 & 2.335 & 46.694 & 46.694 & 2.335 & 46.694 & 46.694 \\
\hline 2 & 1.198 & 23.967 & 70.662 & 1.198 & 23.967 & 70.662 \\
\hline 3 & .658 & 13.162 & 83.824 & & & \\
\hline 4 & .490 & 9.807 & 93.632 & & & \\
\hline 5 & .318 & 6.368 & 100.000 & & & \\
\hline
\end{tabular}




\subsubsection{Compulsiveness}

Table 15. Descriptive Statistics of compulsiveness

\begin{tabular}{lccccc}
\hline & $\mathbf{N}$ & Minimum & Maximum & Mean & Std. Deviation \\
\hline Extravagantness & 150 & 1 & 5 & 2.59 & 1.005 \\
Buying something to make oneself feel better & 150 & 1 & 5 & 2.97 & 1.102 \\
Can't help spending too much money & 150 & 1 & 5 & 2.66 & 1.175 \\
Buying irrelevant products & 150 & 1 & 5 & 2.67 & 1.212 \\
Buying products which can't afford & 150 & 1 & 5 & 2.42 & 1.260 \\
Valid N (list wise) & 150 & & & 2.662 & 1.1508 \\
\hline
\end{tabular}

Table 16. Correlations co-efficient of Compulsiveness

\begin{tabular}{|c|c|c|c|c|c|c|}
\hline & & Extravagantness & $\begin{array}{l}\text { Buying something } \\
\text { to make oneself feel } \\
\text { better }\end{array}$ & $\begin{array}{lr}\text { Can't } & \text { help } \\
\text { spending } & \text { too } \\
\text { much money } & \end{array}$ & $\begin{array}{l}\text { Buying } \\
\text { irrelevant } \\
\text { products }\end{array}$ & $\begin{array}{l}\text { Buying products } \\
\text { which can't } \\
\text { afford }\end{array}$ \\
\hline \multirow{3}{*}{ Extravagantness } & $\begin{array}{l}\text { Pearson } \\
\text { Correlation }\end{array}$ & 1 & $.551(* *)$ & $.665(* *)$ & $.682(* *)$ & $.695(* *)$ \\
\hline & $\begin{array}{l}\text { Sig. } \\
\text { tailed }) \quad(2-\end{array}$ & . & .000 & .000 & .000 & .000 \\
\hline & $\mathrm{N}$ & 150 & 150 & 150 & 150 & 150 \\
\hline \multirow{3}{*}{$\begin{array}{l}\text { Buying something to } \\
\text { make oneself feel better }\end{array}$} & $\begin{array}{l}\text { Pearson } \\
\text { Correlation }\end{array}$ & $.551(* *)$ & 1 & $.603(* *)$ & $.514(* *)$ & $.590(* *)$ \\
\hline & $\begin{array}{l}\text { Sig. } \\
\text { tailed }) \quad(2-\end{array}$ & .000 & . & .000 & .000 & .000 \\
\hline & $\mathrm{N}$ & 150 & 150 & 150 & 150 & 150 \\
\hline \multirow{3}{*}{$\begin{array}{l}\text { Can't help spending too } \\
\text { much money }\end{array}$} & $\begin{array}{l}\text { Pearson } \\
\text { Correlation }\end{array}$ & $.665(* *)$ & $.603(* *)$ & 1 & $.633(* *)$ & $.700(* *)$ \\
\hline & $\begin{array}{l}\text { Sig. } \\
\text { tailed }) \quad(2-\end{array}$ & .000 & .000 & . & .000 & .000 \\
\hline & $\mathrm{N}$ & 150 & 150 & 150 & 150 & 150 \\
\hline \multirow{3}{*}{$\begin{array}{l}\text { Buying } \\
\text { products }\end{array}$} & $\begin{array}{l}\text { Pearson } \\
\text { Correlation }\end{array}$ & $.682(* *)$ & $.514(* *)$ & $.633(* *)$ & 1 & $.785(* *)$ \\
\hline & $\begin{array}{l}\text { Sig. } \\
\text { tailed }) \quad(2-\end{array}$ & .000 & .000 & .000 & & .000 \\
\hline & $\mathrm{N}$ & 150 & 150 & 150 & 150 & 150 \\
\hline \multirow{3}{*}{$\begin{array}{l}\text { Buying products which } \\
\text { can't afford }\end{array}$} & $\begin{array}{l}\text { Pearson } \\
\text { Correlation }\end{array}$ & $.695(* *)$ & $.590(* *)$ & $.700(* *)$ & $.785(* *)$ & 1 \\
\hline & $\begin{array}{l}\text { Sig. } \\
\text { tailed }) \quad(2-\end{array}$ & .000 & .000 & .000 & .000 & $\cdot$ \\
\hline & $\mathrm{N}$ & 150 & 150 & 150 & 150 & 150 \\
\hline
\end{tabular}

** Correlation is significant at the 0.01 level (2-tailed).

Table 17. Total Variance Explained-compulsiveness

\begin{tabular}{lllllll}
\hline Component & \multicolumn{2}{c}{ Initial Eigen values } & & \multicolumn{2}{c}{ Extraction Sums of Squared Loadings } \\
& Total & \% of Variance & Cumulative \% & Total & \% of Variance & Cumulative \% \\
\hline 1 & 3.576 & 71.530 & 71.530 & 3.576 & 71.530 & 71.530 \\
2 & .536 & 10.722 & 82.252 & & & \\
3 & .357 & 7.139 & 89.391 & & & \\
4 & .327 & 6.545 & 95.936 & & & \\
\hline 5 & .203 & 4.064 & 100.000 & & & \\
\hline
\end{tabular}

Extraction Method: Principal Component Analysis. 


\subsubsection{Dogmatism}

Table 18. Descriptive Statistics of dogmatism

\begin{tabular}{lccccc}
\hline & N & Minimum & Maximum & Mean & Std. Deviation \\
\hline Buying similar products & 150 & 1 & 5 & 2.29 & .892 \\
Accepting new products & 150 & 2 & 5 & 4.18 & .592 \\
New products and diversification & 150 & 2 & 5 & 4.21 & .619 \\
Introduction of new products from firms & 150 & 2 & 5 & 4.14 & .724 \\
Valid N (list wise) & 150 & & & 3.705 & 0.70675 \\
\hline
\end{tabular}

Table 19. Correlations co-efficient of dogmatism

\begin{tabular}{|c|c|c|c|c|c|c|}
\hline & & $\begin{array}{l}\text { Buying similar } \\
\text { products }\end{array}$ & $\begin{array}{l}\text { Accepting new } \\
\text { products }\end{array}$ & $\begin{array}{l}\text { New products and } \\
\text { diversification }\end{array}$ & $\begin{array}{l}\text { Introduction of } \\
\text { products from firms }\end{array}$ & new \\
\hline \multirow{3}{*}{ Buying similar products. } & $\begin{array}{l}\text { Pearson } \\
\text { Correlation }\end{array}$ & 1 & $-.467(* *)$ & $-.208(*)$ & -.156 & \\
\hline & Sig. (2-tailed) & & .000 & .010 & .057 & \\
\hline & $\mathrm{N}$ & 150 & 150 & 150 & 150 & \\
\hline \multirow{3}{*}{ Accepting new products } & $\begin{array}{l}\text { Pearson } \\
\text { Correlation }\end{array}$ & $-.467(* *)$ & 1 & $.334(* *)$ & $.254(* *)$ & \\
\hline & Sig. (2-tailed) & .000 & . & .000 & .002 & \\
\hline & $\mathrm{N}$ & 150 & 150 & 150 & 150 & \\
\hline \multirow{3}{*}{$\begin{array}{l}\text { New products } \\
\text { diversification. }\end{array}$} & $\begin{array}{l}\text { Pearson } \\
\text { Correlation }\end{array}$ & $-.208(*)$ & $.334(* *)$ & 1 & $.322(* *)$ & \\
\hline & Sig. (2-tailed) & .010 & .000 & . & .000 & \\
\hline & $\mathrm{N}$ & 150 & 150 & 150 & 150 & \\
\hline \multirow{3}{*}{$\begin{array}{l}\text { Introduction of } \\
\text { products from firms }\end{array}$} & $\begin{array}{l}\text { Pearson } \\
\text { Correlation }\end{array}$ & -.156 & $.254(* *)$ & $.322(* *)$ & 1 & \\
\hline & Sig. (2-tailed) & .057 & .002 & .000 & . & \\
\hline & $\mathrm{N}$ & 150 & 150 & 150 & 150 & \\
\hline
\end{tabular}

** Correlation is significant at the 0.01 level (2-tailed). ${ }^{*}$ Correlation is significant at the 0.05 level (2-tailed).

Table 20. Total Variance Explained-dogmatism

\begin{tabular}{lllllll}
\hline \multirow{2}{*}{ Component } & \multicolumn{3}{l}{ Initial Eigen values } & \multicolumn{3}{c}{ Extraction Sums of Squared Loadings } \\
& Total & \% of Variance & Cumulative \% & Total & \% of Variance & Cumulative \% \\
\hline 1 & 1.883 & 47.065 & 47.065 & 1.883 & 47.065 & 47.065 \\
2 & .937 & 23.418 & 70.483 & & & \\
3 & .672 & 16.798 & 87.281 & & & \\
4 & .509 & 12.719 & 100.000 & & & \\
\hline
\end{tabular}

Extraction Method: Principal Component Analysis.

\subsubsection{Social Character}

Table 21. Descriptive Statistics of social character

\begin{tabular}{|c|c|c|c|c|c|}
\hline & $\mathbf{N}$ & Minimum & Maximum & Mean & Std. Deviation \\
\hline Purchasing and belief & 150 & 1 & 5 & 3.46 & .953 \\
\hline Inviting friends while purchasing & 150 & 1 & 5 & 3.38 & .917 \\
\hline Favoring inner belief in purchasing & 150 & 1 & 5 & 3.55 & .807 \\
\hline Others opinion and confusion & 150 & 1 & 5 & 2.84 & .990 \\
\hline Benefit from other's advice and purchasing & 150 & 1 & 5 & 3.31 & .891 \\
\hline Valid N (list wise) & 150 & & & 3.308 & 0.9116 \\
\hline
\end{tabular}

Table 22. Correlations co-efficient of social character

\begin{tabular}{|c|c|c|c|c|c|c|c|}
\hline & & $\begin{array}{l}\text { Purchasing } \\
\text { and belief }\end{array}$ & $\begin{array}{l}\text { Inviting friends } \\
\text { while purchasing }\end{array}$ & $\begin{array}{l}\text { Favoring } \\
\text { belief } \\
\text { purchasing }\end{array}$ & $\begin{array}{r}\text { inner } \\
\text { in }\end{array}$ & $\begin{array}{l}\text { Others opinion } \\
\text { and confusion }\end{array}$ & $\begin{array}{lr}\text { Benefit from other's } \\
\text { advice } \\
\text { purchasing }\end{array}$ \\
\hline Purchasing and belief & $\begin{array}{l}\text { Pearson } \\
\text { Correlation }\end{array}$ & 1 & $-.278(* *)$ & $.557(* *)$ & & $.370(* *)$ & $-.337(* *)$ \\
\hline
\end{tabular}




\begin{tabular}{|c|c|c|c|c|c|c|}
\hline \multirow{4}{*}{$\begin{array}{l}\text { Inviting friends while } \\
\text { purchasing }\end{array}$} & \multicolumn{2}{|l|}{ Sig. (2-tailed) } & \multirow{2}{*}{$\begin{array}{l}.001 \\
150\end{array}$} & \multirow{2}{*}{$\begin{array}{l}.000 \\
150\end{array}$} & \multirow{2}{*}{$\begin{array}{l}.000 \\
150\end{array}$} & \multirow{2}{*}{$\begin{array}{l}.000 \\
150\end{array}$} \\
\hline & $\mathrm{N}$ & 150 & & & & \\
\hline & $\begin{array}{l}\text { Pearson } \\
\text { Correlation }\end{array}$ & $-.278(* *)$ & 1 & $-.368(* *)$ & $-.339(* *)$ & $.601(* *)$ \\
\hline & Sig. (2-tailed) & .001 & & .000 & .000 & .000 \\
\hline & $\mathrm{N}$ & 150 & 150 & 150 & 150 & 150 \\
\hline \multirow[t]{2}{*}{$\begin{array}{l}\text { Favoring inner belief } \\
\text { in purchasing }\end{array}$} & $\begin{array}{l}\text { Pearson } \\
\text { Correlation }\end{array}$ & $.557(* *)$ & $-.368(* *)$ & 1 & $.254(* *)$ & $-.289(* *)$ \\
\hline & $\begin{array}{l}\text { Sig. (2-tailed) } \\
\mathrm{N}\end{array}$ & $\begin{array}{l}.000 \\
150\end{array}$ & $\begin{array}{l}.000 \\
150\end{array}$ & 150 & $\begin{array}{l}.002 \\
150\end{array}$ & $\begin{array}{l}.000 \\
150\end{array}$ \\
\hline \multirow[t]{2}{*}{$\begin{array}{l}\text { Others opinion and } \\
\text { confusion. }\end{array}$} & $\begin{array}{l}\text { Pearson } \\
\text { Correlation }\end{array}$ & $.370(* *)$ & $-.339(* *)$ & $.254(* *)$ & 1 & $-.483(* *)$ \\
\hline & $\begin{array}{l}\text { Sig. (2-tailed) } \\
\mathrm{N}\end{array}$ & $\begin{array}{l}.000 \\
150\end{array}$ & $\begin{array}{l}.000 \\
150\end{array}$ & $\begin{array}{l}.002 \\
150\end{array}$ & 150 & $\begin{array}{l}.000 \\
150\end{array}$ \\
\hline \multirow[t]{2}{*}{$\begin{array}{l}\text { Benefit from other's } \\
\text { advice } \\
\text { purchasing }\end{array}$} & $\begin{array}{l}\text { Pearson } \\
\text { Correlation }\end{array}$ & $-.337(* *)$ & $.601(* *)$ & $-.289(* *)$ & $-.483(* *)$ & 1 \\
\hline & Sig. (2-tailed) & .000 & .000 & .000 & .000 & \\
\hline
\end{tabular}

** Correlation is significant at the 0.01 level (2-tailed).

Table 23. Total Variance Explained-social character

\begin{tabular}{lcccccc}
\hline Component & Total & $\begin{array}{c}\text { Initial Eigen values } \\
\text { \% of Variance }\end{array}$ & Cumulative \% & Total & $\begin{array}{c}\text { Extraction Sums of Squared Loadings } \\
\text { \% of Variance }\end{array}$ & Cumulative \% \\
\hline 1 & 2.555 & 51.100 & 51.100 & 2.555 & 51.100 & \\
2 & .964 & 19.277 & 70.377 & & & \\
3 & .708 & 14.168 & 84.545 & & & \\
4 & .428 & 8.552 & 93.097 & & & \\
5 & .345 & 6.903 & 100.000 & & & \\
\hline
\end{tabular}

Extraction Method: Principal Component Analysis.

\subsubsection{Need for Uniqueness}

Table 24. Descriptive Statistics of need for uniqueness

\begin{tabular}{lccccc}
\hline & N & Minimum & Maximum & Mean & Std. Deviation \\
\hline Collecting unusual products as being different & 150 & 1 & 5 & 2.96 & 1.123 \\
Losing interest on popular products & 150 & 1 & 5 & 3.01 & 1.093 \\
Avoiding accepted products & 150 & 1 & 5 & 2.74 & 1.184 \\
Looking for stylish products & 150 & 1 & 5 & 2.84 & 1.199 \\
Purchasing products that people don't accept & 150 & 1 & 5 & 2.43 & 1.077 \\
Valid N (list wise) & 150 & & & 2.796 & 1.1352 \\
\hline
\end{tabular}

Table 25. Correlation co-efficient of need for uniqueness

\begin{tabular}{|c|c|c|c|c|c|c|}
\hline & & $\begin{array}{l}\text { Collecting unusual } \\
\text { products as being } \\
\text { different. }\end{array}$ & $\begin{array}{ll}\text { Losing } & \text { interest } \\
\text { on } & \text { popular } \\
\text { products } & \\
\end{array}$ & $\begin{array}{l}\text { Avoiding } \\
\text { accepted } \\
\text { products }\end{array}$ & $\begin{array}{l}\text { Looking for } \\
\text { stylish } \\
\text { products }\end{array}$ & $\begin{array}{l}\text { Purchasing products } \\
\text { that people don't } \\
\text { accept }\end{array}$ \\
\hline \multirow[t]{3}{*}{$\begin{array}{lr}\text { Collecting } & \text { unusual } \\
\text { products as being } \\
\text { different. }\end{array}$} & $\begin{array}{l}\text { Pearson } \\
\text { Correlation }\end{array}$ & 1 & $.493(* *)$ & $.497(* *)$ & $.479(* *)$ & $.558(* *)$ \\
\hline & Sig. (2-tailed) & & .000 & .000 & .000 & .000 \\
\hline & $\mathrm{N}$ & 150 & 150 & 150 & 150 & 150 \\
\hline \multirow{3}{*}{$\begin{array}{l}\text { Losing interest on } \\
\text { popular products }\end{array}$} & $\begin{array}{l}\text { Pearson } \\
\text { Correlation }\end{array}$ & $.493(* *)$ & 1 & $.677(* *)$ & $.483(* *)$ & $.491(* *)$ \\
\hline & Sig. (2-tailed) & .000 & . & .000 & .000 & .000 \\
\hline & $\mathrm{N}$ & 150 & 150 & 150 & 150 & 150 \\
\hline \multirow[t]{3}{*}{$\begin{array}{l}\text { Avoiding accepted } \\
\text { products }\end{array}$} & $\begin{array}{l}\text { Pearson } \\
\text { Correlation }\end{array}$ & $.497(* *)$ & $.677(* *)$ & 1 & $.614(* *)$ & $.584(* *)$ \\
\hline & Sig. (2-tailed) & .000 & .000 & . & .000 & .000 \\
\hline & $\mathrm{N}$ & 150 & 150 & 150 & 150 & 150 \\
\hline \multirow[t]{2}{*}{$\begin{array}{l}\text { Looking for stylish } \\
\text { products }\end{array}$} & $\begin{array}{l}\text { Pearson } \\
\text { Correlation }\end{array}$ & $.479(* *)$ & $.483(* *)$ & $.614(* *)$ & 1 & $.558(* *)$ \\
\hline & Sig. (2-tailed) & .000 & .000 & .000 & & .000 \\
\hline
\end{tabular}




\begin{tabular}{lllllll}
\hline & $\mathrm{N}$ & 150 & 150 & 150 & 150 & 150 \\
$\begin{array}{l}\text { Purchasing products } \\
\text { that people don't }\end{array}$ & Pearson & $.558(* *)$ & $.491(* *)$ & $.584(* *)$ & $.558(* *)$ & 1 \\
accept & Correlation & & & & & \\
& Sig. (2-tailed) & .000 & .000 & .000 & .000 &. \\
& $\mathrm{~N}$ & 150 & 150 & 150 & 150 & 150 \\
\hline
\end{tabular}

** Correlation is significant at the 0.01 level (2-tailed).

Table 26. Total Variance Explained-need for uniqueness

\begin{tabular}{|c|c|c|c|c|c|c|}
\hline \multirow[b]{2}{*}{ Component } & \multicolumn{3}{|c|}{ Initial Eigen values } & \multicolumn{3}{|c|}{ Extraction Sums of Squared Loadings } \\
\hline & Total & $\%$ of Variance & Cumulative \% & Total & $\%$ of Variance & Cumulative \% \\
\hline 1 & 3.178 & 63.564 & 63.564 & 3.178 & 63.564 & 63.564 \\
\hline 2 & .592 & 11.843 & 75.407 & & & \\
\hline 3 & .530 & 10.604 & 86.011 & & & \\
\hline 4 & .414 & 8.282 & 94.293 & & & \\
\hline \multicolumn{7}{|l|}{5} \\
\hline & .285 & 5.707 & 100.000 & & & \\
\hline
\end{tabular}

Extraction Method: Principal Component Analysis.

\subsubsection{Consumer Innovativeness}

Table 27. Descriptive Statistics of consumer innovativeness

\begin{tabular}{|c|c|c|c|c|c|}
\hline & $\mathbf{N}$ & Minimum & Maximum & Mean & Std. Deviation \\
\hline Purchasing familiar products & 150 & 1 & 5 & 2.97 & .951 \\
\hline Enjoy buying unfamiliar products. & 150 & 1 & 5 & 3.67 & .952 \\
\hline Purchasing a brand new product & 150 & 0 & 5 & 3.65 & .977 \\
\hline Having a brand new product first whenever it appears & 150 & 1 & 5 & 2.96 & 1.192 \\
\hline Staying old brands rather than looking for new one & 150 & 1 & 5 & 2.56 & 1.120 \\
\hline Valid N (list wise) & 150 & & & 3.162 & 1.0384 \\
\hline
\end{tabular}

Table 28. Correlations co-efficient of consumer innovativeness

\begin{tabular}{|c|c|c|c|c|c|c|}
\hline & & $\begin{array}{l}\text { Purchasing } \\
\text { familiar } \\
\text { products. }\end{array}$ & $\begin{array}{l}\text { Enjoy buying } \\
\text { unfamiliar } \\
\text { products. }\end{array}$ & 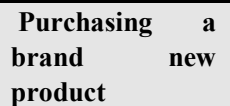 & $\begin{array}{l}\text { Having a brand new } \\
\text { product first } \\
\text { whenever it appears }\end{array}$ & $\begin{array}{l}\text { Staying old brands } \\
\text { rather than looking } \\
\text { for new one }\end{array}$ \\
\hline \multirow[t]{3}{*}{$\begin{array}{l}\text { Purchasing familiar } \\
\text { products. }\end{array}$} & $\begin{array}{l}\text { Pearson } \\
\text { Correlation }\end{array}$ & 1 & $-.627(* *)$ & $-.531(* *)$ & $-.510(* *)$ & $.547(* *)$ \\
\hline & $\begin{array}{l}\text { Sig. } \\
\text { tailed })\end{array}$ & . & .000 & .000 & .000 & .000 \\
\hline & $\mathrm{N}$ & 150 & 150 & 150 & 150 & 150 \\
\hline \multirow[t]{3}{*}{$\begin{array}{l}\text { Enjoy buying } \\
\text { unfamiliar products. }\end{array}$} & $\begin{array}{l}\text { Pearson } \\
\text { Correlation }\end{array}$ & $-.627(* *)$ & 1 & $.626(* *)$ & $.556(* *)$ & $-.526(* *)$ \\
\hline & $\begin{array}{l}\text { Sig. } \\
\text { tailed })\end{array}$ & .000 & . & .000 & .000 & .000 \\
\hline & $\mathrm{N}$ & 150 & 150 & 150 & 150 & 150 \\
\hline \multirow[t]{3}{*}{$\begin{array}{l}\text { Purchasing a brand } \\
\text { new product }\end{array}$} & $\begin{array}{l}\text { Pearson } \\
\text { Correlation }\end{array}$ & $-.531(* *)$ & $.626(* *)$ & 1 & $.472(* *)$ & $-.406(* *)$ \\
\hline & $\begin{array}{l}\text { Sig. } \\
\text { tailed })\end{array}$ & .000 & .000 & . & .000 & .000 \\
\hline & $\mathrm{N}$ & 150 & 150 & 150 & 150 & 150 \\
\hline \multirow[t]{3}{*}{$\begin{array}{l}\text { Having a brand new } \\
\text { product first } \\
\text { whenever it appears }\end{array}$} & $\begin{array}{l}\text { Pearson } \\
\text { Correlation }\end{array}$ & $-.510(* *)$ & $.556(* *)$ & $.472(* *)$ & 1 & $-.355(* *)$ \\
\hline & $\begin{array}{l}\text { Sig. } \\
\text { tailed) }\end{array}$ & .000 & .000 & .000 & . & .000 \\
\hline & $\mathrm{N}$ & 150 & 150 & 150 & 150 & 150 \\
\hline
\end{tabular}




\begin{tabular}{|c|c|c|c|c|c|c|}
\hline \multirow[t]{3}{*}{$\begin{array}{l}\text { Staying old brands } \\
\text { rather than looking } \\
\text { for new one }\end{array}$} & $\begin{array}{l}\text { Pearson } \\
\text { Correlation }\end{array}$ & $.547(* *)$ & $-.526(* *)$ & $-.406(* *)$ & 150 & 1 \\
\hline & $\begin{array}{l}\text { Sig. } \\
\text { tailed) }\end{array}$ & .000 & .000 & .000 & .000 & . \\
\hline & $\mathrm{N}$ & 150 & 150 & 150 & 150 & \\
\hline
\end{tabular}

** Correlation is significant at the 0.01 level (2-tailed).

Table 29. Total Variance Explained-consumer innovativeness

\begin{tabular}{|c|c|c|c|c|c|c|}
\hline \multirow[b]{2}{*}{ Component } & \multicolumn{3}{|c|}{ Initial Eigen values } & \multicolumn{3}{|c|}{ Extraction Sums of Squared Loadings } \\
\hline & Total & $\%$ of Variance & Cumulative \% & Total & $\%$ of Variance & Cumulative \% \\
\hline 1 & 3.076 & 61.520 & 61.520 & 3.076 & 61.520 & 61.520 \\
\hline 2 & .665 & 13.301 & 74.821 & & & \\
\hline 3 & .528 & 10.562 & 85.383 & & & \\
\hline 4 & .400 & 7.992 & 93.375 & & & \\
\hline 5 & .331 & 6.625 & 100.000 & & & \\
\hline
\end{tabular}

Extraction Method: Principal Component Analysis.

\section{References}

[1] Baumgartner. H (2002). "Toward a Personology of the Consumer". JOURNAL OF CONSUMER RESEARCH, Inc. Vol. 29.

[2] Berkman, Harold W. and Christopher C. Gilson (1986), Consumer Behavior: Concepts and Strategies, Kent Publishing Co., Wadsworth, Inc., Boston, Massachusetts.

[3] Chowdhury. I.A. Consumer Behavior. Bangladesh Open University, 2007. P. 310-316

[4] Davis, Keith A., and John W. Newstrom. Human Behavior at Work: Organizational Behavior. New York: McGraw-Hill, current edition.

[5] Deasy, Dorothy. (2000). Express Brand Personality-Let Your Package Do the Talking. Brand Packaging Magazine, March/April.

[6] G. Vani, M. Ganesh Babu, N. Panchanatham, (2010). "Toothpaste Brands -A Study of consumer behavior in Bangalore city". Journal of Economics and Behavioral Studies Vol. 1, No. 1, pp. 27-39.

[7] Harold H. Kassarjian, (1971). "Personality and Consumer Behavior: A Review". Journal of Marketing Research Vol. 8, No. 4 (Nov., 1971), pp. 409-418

[8] Harold W. Berkman, Christopher C. Gilson; Consumer Behavior: Concepts and Strategies, PWS-Kent Publishing Company, 1986

[9] Melvin Herman Marx, William Allen Hillix; Systems and Theories in Psychology, McGraw-Hill Series in Psychology 2006,

[10] Hitesh Bhasin, (2006). "Personal factors affecting consumer buying behavior". From www.marketing91.com
[11] Kaplan. M and Zarrilli. K (2000). "THE ROLE OF FRAGRANCE IN THE BRAND PERSONALITY OF CONSUMER PRODUCTS"

[12] Kassarjian, H. H., and Sheffet, J. M. (1991). "Personality and Consumer Behavior: An update". In H. H. Kassarjian and T. S. Robertson (Eds.), Handbook of Consumer Behavior, $4^{\text {th }}$ ed, 281-303. Englewood Cliffs, N.J. PrenticeHall International Editions.

[13] Lawrence A. Pervin. Wiley, "The Science of Personality" New York, 1996. 471 pp.

[14] Little, Brian R.(1999), "Personality and Motivation: Personal Action and the Cognitive Evolution," in Handbook of Personality: Theory and Research, $2 d$ ed., ed. Lawrence A. Pervin and Oliver P. John, New York: Guilford, 501-524.

[15] Melvin H. Marx and William A. Hillix. (1963)."Systems and Theories in Psychology". New York. McGraw-Hill.

[16] Nakanishi, M. (1972). "Personality and consumer behavior: Extensions". In M. Venkatesan (Ed.), Proceedings 3rd Conference, 61-65. College Park, MD: Association for Consumer Research.

[17] Personality. (n.d). In Wikipedia. Retrieved March 14, 2012, from en.wikipedia.org/wiki/personality

[18] Pervin, L. (1997). Personality: Theory and Research, 7th edition. New York, USA, John Wiley and Sons, Inc.

[19] Ranjbarian and M. Kia, (2010). "The Influence of Personality Traits on Consideration Set Size". European Journal of Social Sciences - Volume 15, Number 2.

[20] Schiffman, L.G. Consumer Behavior / L.G. Schiffman, L.L. Kanuk. Prentice Hall, 2008, p. 114-141

[21] Soga, S., Shimai, S., and Otake, K. (2002). As analysis of the relationship between aggressiveness and personality traits of children. Japanese Journal of Psychology, 73, 35836. 